\title{
Cultural policy governance, sub-state actors, and nationalism: a comparative analysis based on the Spanish case
}

\author{
Mariano Martín Zamorano \\ CECUPS / UNIVERSITAT DE BARCELONA \\ marianozamoranolaub.edu
}

Received: 31/07/2016

Accepted: 29/01/2017

\begin{abstract}
Since the nineties, regional governance has acquired an increasing importance for cultural policies in the developing world. However, the elements determining the development of unequal models of cultural governance within the same country, and the differential relevance of subnational nationalism in this regard, have not been completely explained. In this article we develop a comparative analysis of the autonomous cultural policies of Catalonia, Madrid, and Andalusia. Thus, we explain how their models of horizontal governance are determined by common elements, such as the model of public policies, and other specific differential factors such as historical and industrial local heritage and regional identity, where nationalism is specifically relevant.
\end{abstract}

Keywords: cultural policy, governance, nationalism, state of the autonomies.

Corresponding author: Mariano Martín Zamorano. CECUPS - Centro de Estudios sobre Cultura, Política y Sociedad (Universitat de Barcelona) Facultad de Economía y Empresa. C/ Teniente Coronel Valenzuela, 1-11, 08034 Barcelona.

Suggested citation: Zamorano, M. M. (2017). Cultural policy governance, sub-state actors, and nationalism: a comparative analysis based on the Spanish case. Debats. Journal on Culture, Power and Society, 2, 79-93. doi: http://dx.doi.org/10.28939/ iam.debats-en.2017-6

\section{INTRODUCTION}

The cultural policies drawn up in Spain over the last 30 years have been examined through a wide range of analytical and conceptual lenses, and have been covered in their state, regional, and local spheres. The academic literature has dealt with: (a) the structural development and purposes of central government's cultural management (Rubio, 2008a; Rubio, 2005); (b) the diversity of regional policies and the ways they have been articulated with state public administration (Bouzada, 2007; Rius and Zamorano, 2014); (c) the relationship between local cultural policies and intermediaries (Martínez and Rius, 2012; Rius, et al., 2012). This scholarly output has been enriched with monographs and various reports on the workings of the state system as a whole from a more descriptive, institutional perspective (Real Instituto Elcano de Estudios Internacionales y Estratégicos, 2004; Villarroya, 2012a). A recent collaborative work has brought together many of the major authors in the field in a compendium covering the last 30 years of cultural policies in Spain (Rius and Rubio, 2016).

Many of these studies highlight the various shortcomings in the multi-level co-ordination of cultural policy in Spain. Here, the framework of cultural policy was one marked by wrangling between central government administration and regions ['autonomous communities'] with a historic claim to nationhood. These elements were 
present in studies analysing identity-forming processes in cultural policy (Crameri, 2008; Villarroya, 2012b) and programmes in relation to their legitimising discourses (Barbieri, 2012b). Other studies have examined: the degree of Federalism (Rius and Zamorano, 2014); governance (Bonet and Negrier 2010; Bouzada, 2007); and foreign cultural policy (Zamorano and Rius, 2016). In studying the various kinds of actions undertaken by public administrations in the cultural field, the literature has stressed the importance of the various interrelationships between cultural policy programmes and state national projects. For example, some of the correlations between political nationalism (whether 'Spanish' or of a 'regional national' variety) and the lack of inter-governmental co-ordination have been studied. The frequent lack of inter-governmental articulation found in cultural policy in the country stems from the partisan political scenarios found in Spain's state institutions (Ruis and Zamorano, 2014).

Here, one should note that the cited corpus of studies has not focused on identifying and explaining the differentiating 'national' dynamics at work in regional cultural policies. On the one hand-with the exception of the emerging perspective of sociological analysis of cultural policy (Rodríguez and Rius, 2012b)—the scope of these studies has been confined to the network of socio-institutional relationships. On the other hand, there have been no comparative studies analysing the kinds of links between 'identity' and political policies in Spain's various autonomous communities [regions]. ${ }^{\mathbf{1}}$ These shortcomings stem in part from the fact that studies in this field depend on policy analysis (which is pre-eminently of an institutional nature). Such studies tend to skate over socio-cultural features and sectors which have a bearing on the links between nationalism and governance of Arts and heritage in

1 While there are studies analysing 'identity' processes in regional cultural processes-especially in the Catalan case (Barbieri, 2012a; Villarroya, 2012a; Crameri, 2008)-there are no comparative studies. It is worth mentioning that some studies have focused on certain aspects from a comparative perspective, such as cultural facilities (Rubio and Rius, 2012), or the study directed by Rodríguez and Rius (2012a), which analyses Spanish cultural policies from a systemic standpoint. each region. In particular, differences in forms of social participation in the public administration of culture should be taken into account. These forms range from open, horizontal governance to models of corporate relationships between cultural actors and governments.

In this paper, we comparativly analyse three cultural policies carried out by different regions with the aim of evaluating the elements determining the forms of horizontal governance adopted in each case. That is to say, we delve into the main 'top-down' and 'bottom-up' mechanisms and dynamics in the relationship between regional public administrations and socio-cultural actors.

To this end, we take three key variables into account: (1) articulation of the relationship with the industrial fabric and heritage; (2) its model of action; (3) the role played by regional identities and their orientation. Thus we analyse the socio-institutional fabrics underpinning culture in three autonomous communities with different national dynamics: Andalusia, Catalonia, and Madrid. These three regions are not only the biggest in Spain in terms of population, they also exemplify three radically different models of identity and ideological governance. Andalusia has a unique regional character that is highly integrated into Spanish national identity. The region has been governed by the Spanish socialist party, PSOE, the Partido Socialista Obrero Español, since Andalusia became an autonomous community. Catalonia is a historic nation in which demands for self-determination enjoy broad popular support. The region's system of political parties, electoral sociology, and political culture clearly set it apart from the rest of Spain. Last, there is Madrid, which has been governed by the right-wing Spanish conservative party, the PP (Partido Popular) since the 1990s. It is an autonomous community with no regional identity and in which central government tacitly plays the leading role.

In presenting these three cases, the literature is examined under the following four headings:

(1) the key elements in models of cultural policy and forms of governance; 
(2) a brief summary of the evolution of cultural policy in Spain, its aims, regional organisation, and the strategies of the main cultural actors;

(3) the three cases and their socio-institutional dynamics in the cultural policy sphere. This is based on desk research, drawing on direct and indirect sources $^{2}$ that feed into the qualitative analysis;

(4) A comparative analysis between nationalism and the various forms of horizontal governance and the Spanish state, distinguishing between different forms of corporatism and cultural participation.

\section{MODELS OF CULTURAL POLICIES AND THE EVOLUTION OF CULTURAL MANAGEMENT}

The setting up of France's Ministry of Culture in 1959 marked the beginning of the institutionalisation of cultural policy. France's example was followed in 1965 by the United States, who set up the National Endowment for the Arts, and in Great Britain, with the Office of Arts and Libraries. Since then, English-speaking countries and those in Northern Europe have chosen different models of cultural policy, and these models have inspired cultural policies to be drawn up around the world. France fostered the incorporation of cultural sectors and actors (cultural democracy), applying an interventionist strategy that was mainly Paris-centred (Urfalino, 1996). In contrast, the English-speaking world mainly adopted a decentralised approach to cultural management, with the private sector being given a greater role and the state a more limited one, based on the arm's length principle (Mulcahy, 1998). ${ }^{3}$

\footnotetext{
2 One should note that many of the key documents studied are drawn from the research project El sistema de la politica cultural en España [translated as Spain's Cultural Policy System], funded by Spain's Ministry of Education and Culture. Project CS02008- 05910, the National Scientific Research Plan, Development and Technological Innovation. Its Lead Researcher was Dr. Arturo Rodríguez Morató and the author of this paper took part in the project.

3 Following this order, these refer to the dominant theoretical models. Miller and Yúdice (2004) have relativised the notion of there being little state intervention in the English-speaking world.
}

Various distinctions have been drawn between cultural models, depending on the role played by the state in the cultural sector. These distinctions take into account factors such as each model's role in redistributing cultural capital and its administrative mechanisms. Four state cultural models have been identified: the Facilitator, the Sponsor, the Architect, and the Engineer (Hillman and McCaughey, 1989), listed from least to most state intervention and control in the artistic field, and with different strategies in the relationship between public administrations, associations, and the private sector. One can discern three broad models in the cultural policy field: the Liberal Model (characterised by weak state intervention), and the European Model (with a powerful public administration that strongly promotes culture), and the Nordic Model (active, decentralised government intervention that has an impact at the local and community levels (Zimmer and Toepler, 1996; Zimmer and Toepler 1999).

Here, it has been noted that the nation-state's intervention in this field has weakened as regional cultural policies have been beefed up (Menger, 2010; Pongy and Saez, 1994). The latter have proved capable of reproducing and re-directing the traditional aims of state cultural policies, fostering different identity-based projects (Villarroya, 2012), and for developing cultural industries at the regional scale (Pérez and Vives, 2012). Diverse discursive constructs have strengthened the hand of regions in the cultural sphere (Johannisson, 2010) and have legitimised the special forms taken by national models (Gattinger and Saint-Pierre, 2008). This re-configuration of public cultural action has given rise to various kinds of governance, which are not without their drawbacks. Here, Bonet and Negrier (2010) highlight the tensions between efficiency and legitimacy in Spain's cultural policies. These tensions stem from the historical tussle between the country's centralising state and its peripheral regions, with the latter doing their utmost to resist national and cultural assimilation. These authors argue that Spain's cultural policy has been built through a dialectic between standardisation and differentiation and is manifested by various 
transfers of institutional powers from the centre to the periphery. The authors compare this situation with other countries, such as France, where legitimacy lies with the central government and takes a top-down form. Although cultural policy works within the framework of national models, it seeks to manage sectoral dynamics in all cases-for example, by fostering artistic output, protecting heritage, fostering a common identity, and treating culture as a way of life (Garretón, 2008, p. 77). Thus, in cultural terms, this activity has a representational dimension. State administrations come up with different strategies for resolving the relationship between state and culture, depending on official categories comprising the common identity of the groups making up society. In this respect, cultural policy delimits which artistic and heritage goods must be rescued, conserved, and disseminated, and the public they cater to (Dubois, 1999; Lebovics, 2000). Thus, culture becomes an instrument that may favour a given social order, through its fostering of new practices and the building of social representations, some of which are of a national nature (Zolberg, 2007).

Each nation's institutions, and political and cultural idiosyncrasies are reflected in its cultural policy. They stem from the special historical, social, and cultural features of each state (for example, multilingualism or multi-nationalism). Two structural elements -socio-cultural heritage and path dependence (Kangas and Vestheim, 2010)_-are two of the key variables defining a state's public administration. ${ }^{\mathbf{4}}$ These elements shape cultural policy models (making them more liberal or more interventionist, as the case may be), predetermining their content and influencing inter-governmental relationships.

4 While it is only right to mention the key factors in structuring cultural policy, these schemes need to be compared in each context. This is because the literature has shown that the political agenda can also be based on other variables and interests, such as economic and political instrumentalisation (Barbieri, 2015; Gray, 2008; Parker and Parenta, 2009). Various agency factors have been shown to be determinants in the orientation and transformation of cultural policies.

\section{THE GOVERNANCE OF CULTURAL POLICY AND ITS SOCIO-CULTURAL FOUNDATIONS}

The governance of cultural policy has waxed over the last few decades. This has occurred in a context in which: (a) cultural diversity has shaped government policies (Taylor, 1997; (b) decentralisation and an opening up to social actors have become key criteria in approaching cultural policies (Vidal, 1997). Governance is a model for implementing cultural policies and conducting theoretical analysis. It emerged from the crisis of the Weberian 'vertical' model of government and its focus on the application of norms (Peters and Savoie, 1995, p. 389). The old hierarchical scheme of government was based on legal frameworks and rigid programmes. The new school of 'governance' supposes that the state must create forums for social participation and deliberation to accommodate changing public demands for political action.

This framework considered two interrelated governance processes in the field of government management: (a) hierarchical processes; (b) processes based on openness to various social action groups. Hence the adoption of the bottom-up governance model, which in some cases led to greater democracy within the liberal state as a result of community intervention in public policy-making (Peters, 1995). Thus cultural policy governance has been presented as an opportunity to better cater to national and regional diversity in the cultural field. The bottom-up approach and constant, pro-active state openness to community actors is a hallmark feature of Scandinavian cultural policy models (Blomgren and Johannisson, 2014), which may favour greater representation in political and cultural matters.

Nevertheless, Peters considers the deterministic link between governance and better political representation as a purely reductionist argument. One of his reasons is that active recognition by the state of a changing society may lead to over-compartmentalisation of government and lead to inefficiency and legal ambiguity (Peters, 1995). In this respect, governance systems in the cultural policy field have also exhibited various corporate vices that limit community participation. Corporatism has been characterised as a government model with: (a) a 
strong, dirigiste state; (b) various restrictions on interest groups' freedom and activity; (c) the incorporation of these interests as part and parcel of the state system, with representatives of these interests, and as helpers of the state in administering and furthering public policies (Wiarda, 1996, p. 8). Corporatism in cultural policy governance may incorporate the administrative fabric of the state and social bodies-something that has been analysed in relation to: Catalonia's cultural projection abroad (Zamorano, 2015), finnish cultural policies (Kangas, 2001, p. 61), and multinationals' influence over the political agenda. Thus, these dynamics can be structured around multiple extra-cultural aims, which may range from favouring certain corporate interests in cultural industries to building national hegemony at the sub-state level.

THE INSTITUTIONAL EVOLUTION OF CULTURAL POLICIES IN THE SPANISH STATE

The 1978 Spanish Constitution (SC) established Spain as a constitutional monarchy and a decentralised state. Its provisions led to three tiers of government: municipalities, provinces, and 'autonomous communities' (ACs) [regions with some self-government], Given the existence of various 'nations, and regions' (Article 2, SC), these were made into fully-fledged political and administrative units, with the state comprising self-governing regions is of a quasi-federal nature. One of its unusual features is the decentralisation of social policies (Aja, 2007). The so-called differentiating features (in the language used by the SC) found in each autonomous community have been operationalised in ways that have given rise to an 'asymmetric federalism' (López, 1999). Stemming from this highly 'open' framework, judicial interpretations of the Constitution's provisions have facilitated either decentralisation of powers to the regions or their recentralisation by the state, depending on each case.

The 1978 SC partially recognised the culturally multi-national nature of Spain. Thus, the so-called Transition Pact [that is to say, the transition from a fascist dictatorship to a constitutional monarchy] recognised Spain's constituent 'nationalities' (Article 2, SC) and the country's cultural and linguistic diversity (Article 3 , SC) $)^{5}$. In the cultural policy field, the SC fosters active state participation with a view to ensuring citizens' access to culture (articles 25.2, 44.1, 48, 50, SC). It also sets out the central government's powers in conserving and protecting the national cultural heritage, state museums, archives, and libraries (Article 149.1.28, SC). Likewise, central government assumes the legislative tasks affecting intellectual property rights, ensuring free expression, and regulation of the media.

In addition, Article 149.2 of the SC is of a quasi-federal nature, stating: "Without prejudice to the powers that may be exercised by the regions, the state shall consider fostering culture as one of its essential duties. To this end, it shall facilitate cultural communication among the autonomous communities". Within this framework - according to the SC-the regions assume various powers in the cultural dissemination and promotion in their respective areas. These powers include: language, heritage, libraries, the Arts, museums, and conservatories (articles 148.1.15; 148.1.16, and 148.1.17, SC). As a result, the present powers of Spain's regions are wide-ranging, their exercise being affected by the unequal development of each region's Statute of Autonomy.

Spain's 'cultural nations' used this framework to promote their regional identities through cultural policies. This enabled them to give an impetus to the decentralisation of public policies on culture and heritage (Rubio, 2008a; Rius and Zamorano, 2014). Such policies have given rise to political asymmetry, with Statutes of Autonomy in regions with their own language granting more powers on cultural matters (Zallo, 2011). The relative independence of regions' cultural policies has led to diverse isomorphic and symmetrical processes in autonomous communities and this tier of government to have a growing impact on cultural matters. As a result, cultural policy in Spain

\footnotetext{
5 The official, majority language throughout Spain is Castilian ['Spanish']. There are four other languages: Catalan, Galician, Basque, and Occitan are co-official languages in six of Spain's autonomous regions. In addition, there are two more tongues: Asturian-Leonese, and Aragonese, which are not co-official languages but receive less protection in three of the country's autonomous communities.
} 
today stems from independent institutional dynamics, is largely a regional affair, and is of a fragmented, disparate nature (Rodríguez and Rius, 2012a).

Another important point is that the central government's cultural policies are the heirs of a Bourbon monarchist tradition (absolutism wedded to centralisation); (Bouzada, 2007). Things were made worse by General Franco's fascist dictatorship, which lasted for almost four decades. This led to suppression of regional identities and the weakening (or even scrapping) of the institutions of 'high culture' (Rubio, 2008a). Thus the rapid process of decentralisation and transfer of resources to regional governments between 1979 and 1985 led to the creation of a multi-cultural concept of Spain that ran counter to the policies pursued by the Ministry of Education and Science (MEC), which was heavily influenced by the French model (Bouzada, 2007). The belated construction of a welfare system and Spain's accession to the European Economic Community (EEC) in 1986 led to the slow updating of cultural policies, in keeping with the democratic paradigm and the avowed aim of facilitating citizens' access to culture. In contrast, central government has never developed a federal dimension in regional co-ordination or in cultural policy. It has merely confined itself to the formal recognition of linguistic and cultural diversity and regional powers in such matters. On the one hand, cultural policy in post-dictatorship Spain was partly stripped of both its its centralism and the propagandistic role it had played under Franco. To some extent, the organisation of the MEC bucked this trend. The Ministry was given some federal attributes and limited powers for fostering inter-governmental initiatives in its field (Rius and Zamorano, 2014).

\section{THE CATALAN GOVERNMENT'S CULTURAL POLICY: FROM TOP-DOWN GOVERNANCE TO LIMITED INSTITUTIONAL OPENNESS} The first Convergència i Unió (CiU), ${ }^{6}$ government set up the Department of Culture in 1980. This enabled Catalonia to pursue its own cultural policy, which sought to foster artistic activity and heritage throughout the country.

6 The CiU was a Conservative, Liberal, Nationalist federated party that governed Catalonia between 1978 and 2003.
The first priority was to build a decentralised network of facilities and to set up a project for restoring Catalan to daily use [the language had been repressed under the dictatorship] (Villarroya, 2012a; Barbieri 2012a). The concept in Catalonia is termed Normalització Lingüística and amounts to language planning with a vernacularisation focus. Normalització Cultural [cultural planning] was the term used to designate the institutionalisation of Catalan culture after the dictatorship's demise. This process was characterised by Fernàndez (2008) as the abandonment of cultural resistance (stemming from the dictatorship's imposition of 'Spanish' culture) and the adoption of policies disseminating elements of Catalan national identity.

The Department of Culture's activities were limited at the time pending transfer of resources from the central government. The problem was compounded by the lack of infrastructure and a tiny budget (Departament de Cultura, 1983). The Department's activities incorporated contributions by various artists and intellectuals who had been dissidents during the Franco regime and was seen as a logical channelling of national interests at the time. This gave rise to the subsequent institutionalisation of these links. ${ }^{7}$ It was against this background that the Catalan government developed a Central European kind of cultural policy, characterised by setting up a corporatist network which incorporated initiatives to promote the use of Catalan (Zallo, 2011; Villarroya, 2012b). The CiU put greater stress on heritage (Subirós, 1998) yet there were constant tensions in Catalan cultural policy regarding definitions and contents between hegemonic actors and subsidiary ones (Giner, Flaquer, Busquet and Bultà, 1996).

The Department of Culture's resources grew markedly, as did its freedom of action. This was despite the fact that the lion's share of funding for culture in Catalonia had

\footnotetext{
7 This revealed the strong link between cultural policies and identity in Catalonia, especially through heritage, language, and communication strategies (Villaroya, 2012b; Crameri, 2008). These strategies tended to be based on isomorphic institutions and discourses and thus on great historical achievements and tales.
} 
traditionally come from local administrations (Rius et al., 2012, p. 179). In this context, the focus on heritage and the establishment of large public institutions led to a top-down approach and was accompanied by governance fostering cultural production (Barbieri, 2012b, p. 94). Public-private consortiums were one of the instruments of this policy. This approach allowed the Catalan government to gain both freedom of action and legitimacy in the cultural field, bringing together various artistic and heritage sectors which were systematically incorporated into the government's field of action. The structuring of this system around Catalonia's Department of Culture was considered as a form of clientelism based on dishing out subsidies (Font, 1991), a form of relationship with the cultural field based on associations (Barbieri, 2012b, p. 160). This approach fostered and strengthened the centralisation of high-profile facilities in Barcelona and was highlighted as one of the things creating a gulf between Catalonia's autonomous administration and the lower-tier local administrations and agents in the region (Mascarell, 1999).

A new feature that emerged in the early 2000s was the renewed promotion of Catalan cultural industries and projection of the nation's culture abroad. Here, the setting up of the Catalan Institute of Cultural Industries [Institut Català de les Indústries Culturals-the ICIC) in the year 2000 was a watershed. The ICIC initially reported to the Department of Culture and, from 2002 onwards, to the Ramon Llull Institute (IRL in its Catalan acronym). This intervention by the Catalan government in cultural industries continued throughout the first tripartite government (2003-2006). Yet the various measures aimed at articulating the Department of Culture's policies at the local level were not drawn up until the second tripartite government (2006-2009); (Rius et al., 2012, p. 179). The creation of the National Council for Culture and the Arts [Consell Nacional de la Cultura i de les Arts-CoNCA] and the modernisation of the system forged a mixed cultural policy model—a kind of halfway house between the Central European and Liberal models. This model gradually took root through the region (Rubio and Rius, 2012), despite the tensions and contradictions between political control and delegation (Chávez, 2012). Within this general trend, Catalan cultural policy has mainly been oriented building national infrastructure for the Arts and Culture but without a clear cultural strategy. It has been characterised by corporatist governance aligned with the aim of promoting Catalonia as a nation. ${ }^{8}$

\section{CULTURAL POLICY IN ANDALUSIA: TOP-DOWN GOVERNANCE AND ITS REDISTRIBUTIONAL SLANT}

Andalusia set up its Ministry of Culture in 1978 in a government re-organisation that predated the region's designation as an autonomous community. The Ministry was charged with fostering and disseminating culture (as was the case in Spain's other regions), combining this activity with welfare policies. New powers and resources were transferred from central government to Andalusia to these ends. ${ }^{9}$ New cultural spheres were established and programmes set up to foster culture as 'a way of life'. The discourse was more closely linked to modernisation of the region than to Andalusia's identity (Pérez and Vives, 2012). Andalusia's policies since then have been characterised by a progressive orientation towards the region's cultural sectors. A special feature of Andalusia's policy has been its close articulation with the state's deliberate cultural promotion of 'Spanish' (that is to say, Castillian) nationalism (Pérez and Vives, 2012).

Andalusia's Ministry of Culture initially combined its programme with a traditionalist concept of the region's identity and a strategy in the artistic and heritage fields that was in keeping with principles of cultural democracy. Up until 1982, Andalusia's policy was characterised by decentralisation in the cultural and artistic sphere, following the same principles as those adopted by Spain's Socialist central government. Then came a second stage,

8 Within this framework, many key cultural actors and groups forged levels with every tier of public administration and had to grapple with all kinds of policy approaches. For example, the Catalan audiovisual sector's dealings, dealings with Spain's Ministry of Culture in the 1980s and 1990s (Zamorano, 2015; Barbieri, 2012b)

9 Here, one should note that Andalusia took on the management of three leading institutions that were previously under the state's wing: the Alhambra and Generalife Gardens (Granada), the Museum of Fine Arts, and the General Archive of The Indies (Seville). 
with Rafael Román Guerrero heading the Ministry, when powers and resources were transferred from central government to Andalusia. This was accompanied by further development of the region's welfare policies. With a few exceptions, the transfer of powers did not lead to any major clashes in the first decade (Pérez and Vives, 2012, p. 69). Nevertheless, there were tensions between the modernisation fostered by the new regional administration (and supported by cultural sectors) and the state administration. The latter was prone to continue the 'cultural assimilation' policies of the dictatorship. Under the Franco regime, anything Andalusian was grist to the mill of the regime's narrow, propagandistic notion of 'pure Spanishness' (Santos, 1991). This vice has made it easy for Andalusia to align its cultural policy with that of the central government, no matter which party happens to be in power. ${ }^{\mathbf{1 0}}$

Modernisation of the cultural administration and its re-structuring of functional lines was undertaken straight away. The model used was that of the Ministry of Culture, directed by Javier Solana (1982-1988). The new administration, now split into cultural sectors, temporarily ditched an approach based on cross-cutting policies (partly heritage-based) fostering Andalusian identity. Instead, it focused on working with associations in general and with corporate sectors in particular (Pérez and Vives, 2012). In governance terms, a key innovation in the early 1990s was the creation of the Public Company for the Management of Cultural and Sports Programmes (EPGPC in its Spanish acronym), ${ }^{\mathbf{1 1}}$ in which various cultural companies in the region took part. During Carmen Calvo's spell as Andalusia's Minister of Culture (1996-2004), ${ }^{\mathbf{1 2}}$ EPGPC_-which reported to the General Directorate for the Fostering of Culture-was beefed up as an

10 This was reflected in various joint projects and the solution of key conflicts, such as the creation of a trust to manage the Alhambra complex in 1986.

11 The General Plan for Cultural Goods 1989-1995 was drawn up, while the General Plan for Cultural Goods 1996-2000 established new decentralisation and innovation guidelines in the heritage field.

12 Carmen Calvo was appointed Minister of Culture in the 2004-2008 legislature. instrument for articulating the governance of cultural policy between the private and public sectors. This stage also allowed progress to be made in the project for cultural democracy, combining, strengthening, and modernising Andalusia's public institutions and facilities, as well as promoting decentralisation and regional management.

Andalusian cultural industries are concentrated in two main centres: Malaga and Seville, and have several various important heritage sites (Granada, Seville, Cordoba), Andalusia also has many performing arts events serving this policy agenda. Yet the incorporation of certain groups in government activity (especially in connection with the EPGPC), reflects the interests of lobbies and corporations (Pérez and Vives, 2012, p. 76). Although 'culturally democratic' and decentralised, the region's policies have steered an erratic course between fostering culture for the masses and pandering to corporate interests.

\section{THE CULTURAL POLICY OF THE MADRID REGION: A SUB-SYSTEM OF STATE CULTURAL GOVERNANCE}

Spain's central government transferred various powers to the Madrid autonomous community's Ministry of Culture in 1985-much later than in most other regions (Royal Decree 680/1985 of the 19th of April). The Ministry's activities only began to take a systematic form at this stage. As Rubio noted (2008b), what sets Madrid's cultural policies apart is the fact that the city is Spain's Capital. The fact that most of the state's administration is based in the city gives the Madrid region great potential for boosting cultural industries and institutions in the region. ${ }^{\mathbf{1 3}}$ Most of the public bodies dealing with heritage date to before the Franco dictatorship. These have been complemented by a network of private charities and new public-private partnerships set up over the last 30 years, such as the Museo Reina Sofía (Rubio and Rius, 2012). Nevertheless,

13 The great institutions of the monarchic enlightenment and the national museums are found in Madrid - for instance, the Prado, the National Library, and the National Archaeological Museum. 
the autonomous government and the Madrid Provincial Board [Diputación] play a secondary role in the administration of this institutional conglomerate (Rubio, 2008, p. 211). Instead, it is the Madrid City Council and the Ministry of Culture that play the leading role in the region's cultural policies. ${ }^{\mathbf{1 4}}$

The concentration of public and private (charitable) cultural institutions, the fabric of cultural industries (Ministry of Education and Culture, 1995) and, in general, cultural production and consumption have been key factors in guiding the region's cultural policies (Rubio, 2008b, p. 213; Rubio, 2008b, p. 213). In this respect, regional identity played no part in setting up this cultural policy. Both left-wing governments (PSOE governed the region between 1983 and 1995) and right-wing ones have focused their discourse on the existing cultural diversity (Rubio, 2008b). In contrast, the socio-cultural debate in the region's policies focus on representing the region as a whole (that is to say, Madrid itself and the Madrid region); (García de Enterría, 1983) and as the heart of the Spanish state. Thus the political and regional element-enshrined by Madrid's rich heritage and industrial muscle-has been key in defining (a) the lines of regional governance and (b) their articulation with local cultural groups and companies-both strongly concentrated in the Capital.

Although the region's cultural policy has been marked by this secondary role, various advances were made in the 1990s in terms of net budget and of intervention in the film and audiovisual sector. A Film Promotion Board for The Madrid Region (Royal Decree 100/1994 of the 13th of October) was set up to boost these activities. Since then, the cultural policy model has shifted towards setting up public-private bodies, such as the Madrid Audio-visual Consortium, created in 2005.15 There is also the Madrid Network, a body fostering the creative sector (set up in 2007) whose discretionary

14 Historically, many of the great cultural institutions, such as the Prado, were funded and run by central government and made up a sizeable chunk of state spending on culture.

15 Royal Decree 54/2005, of the 23rd of June, Government Council. disbursement of public funds has been questioned. ${ }^{\mathbf{1 6}}$ In contrast, the model for other artistic sectors has been based on collegiate bodies comprising sectoral associations that deliberate, make proposals to the public administration, and/or carry out joint activities with it (Rubio, 2008b, p. 226). Yet this process has neither been accompanied by strategic planning of a regional cultural policy nor the establishment of stable, decentralised governance. Unlike in Catalonia, there has been very little mobilisation of Madrid's cultural sector in questioning the regional government's role (Rius, 2005; Rubio and Bonnin, 2009).

\section{DISCUSSION AND CONCLUSIONS: FORMS OF GOVERNANCE, CULTURAL POLICY MODELS, AND THE SOCIO-CULTURAL SPHERE}

Comparative analysis of regional cultural policies reveals that their forms of horizontal governance have been determined by three elements. The first is the legal, administrative, and state political-cultural framework. In the Spanish case, a central government administration co-exists with regional actors. The central administration has drawn up cultural policies that broadly follow the Central European model (and is characterised by having little ability to articulate the system as a whole, notwithstanding Spain's drive to re-centralise government). Regional actors, on the other hand, adopt different strategies and orientations, whether liberal or of an 'architectural' nature (Zamorano and Rius, 2014). The system has been articulated in a complex way with in local governments. This tier of public administration has the biggest state cultural policy budgets and is closest to the creators and distributors of culture. Thus, collaboration and conflict among governmental actors stemming from party politics have shaped the regional governance of artistic and cultural sectors. In this respect, one should highlight the impact of regional boards and local governments on the varied roles and orientations exhibited by intermediate tiers of public administration (Rius et al., 2012).

16 See: http://politica.elpais.com/politica/2015/05/17/ actualidad/1431894177_454214.htm 
While relations between Catalan and central governments have shown ever-widening rifts (and little co-ordination with local government), Andalusia's Ministry of Culture has maintained a fluid relationship with the State Public Administration. This even facilitated transfers of powers and resources to Andalusia during spells of Socialist government. Lastly, as one can see in Table 1, the Madrid region has a very small budget for culture, which has historically been the case. ${ }^{\mathbf{1 7}}$ This situation has been facilitated by the fact that the Madrid government is a kind of sub-system of the central government's political and cultural system.

Second, the kinds of regional cultural policy governance analysed in this paper have also been determined by the models implemented by each regional government. Here, one can see how progressive institutionalisation of cultural policy at the regional level has led to growing demands for more powers and resources. Nevertheless, these demands have varied in strength and have been based on different arguments. The Catalan government has continually demanded more powers and resources in the cultural field (Department of Culture, 1983) and has taken a systematically nationalist line in cultural policy, clearly setting it apart from Spain's centralised systems. Bearing in mind this evolution, Rius, et al. (2012, p. 199) have noted that Catalonia's cultural policy does not fit into present theoretical models, and argue that Catalonia's model is a mixed one, combining elements of the Liberal model and of the Central European one (Gattinger and Saint-Pierre, 2008). In Andalusia, cultural policy has also gained ground but largely takes the form of cultural democracy oriented towards regional articulation. In contrast, cultural administration in the Madrid region has followed the Central European model but at a fairly low level and is focused on the Capital. Its transformations and changes are of a modernising nature and have been fostered in a top-down fashion by Madrid's Ministry of Culture, especially during Carmen Calvo's term of office (Rubio and Rius, 2012, p. 20).

Third, the governance of cultural policy was influenced by: links with actors in the field; the special features of regional markets for culture; social demands (national, sectoral, and so on) emerging in each case. As one can see from Table 2, Andalusia's rich heritage meant that cultural initiatives in the museum and archaeology fields have been given much greater weight than those for cultural industries. In contrast, Madrid and Catalonia, two major centres for cultural industries serving the whole of Spain, have required a more active approach to the international promotion and projection of these sectors. In Catalonia, this need led to a clear sectoral demand that was mainly met by setting up the ICUB and a strategic programme for promoting the industry. The Madrid region took some steps in this direction but central government still plays the leading role.

Table 1. Budget and demographic data by Autonomous Communities [self-governing regions] (2014-2015)

\begin{tabular}{|c|c|c|c|c|}
\hline & & ANDALUSIA & MADRID & CATALONIA \\
\hline SPENDING ON CULTURE BY & & $162,095,000$ & $80,175,000$ & $245,437,000$ \\
\hline AUTONOMOUS COMMUNITY $\mathbf{1 8}$ & $\%$ State spending & $15.5 \%$ & $7.7 \%$ & $23.4 \%$ \\
\hline POPULATION IN 2015) & Absolute value & $8,405,303$ & $6,424,843$ & $7,408,853$ \\
\hline
\end{tabular}

SOURCE: Annual report on culture statistics 2016, Ministry of Education, Culture and Sports / the Spanish National Statistics Office

17 After the cuts made to the budgets of all regions over the last few years

18 Data for 2014. 
Thus, there is a complex link between the heritage and the production aspects of each region on the one hand (Table 2), and governance on the other. The efforts made by Catalan cultural industries and the impact of Language Planning begun during the last decade mark a big difference with the programmes drawn up by the Madrid region. In the latter case, cultural policies have played second fiddle to the strategies of central and local governments. In Andalusia's case, cultural policies are heritage-based and were a factor in the decision to adopt a decentralised approach.

Taking the city of Madrid as the focus for heritage and cultural production must be seen against the local context of: (a) much weaker demands for decentralisation; (b) a regional administration that has not defined itself as a key actor for the cultural sector. This situation differs greatly from that in Catalonia, where "there has been fierce debate on the direction taken by large cultural facilities" (Rius, 2005). One can say that the culture production and heritage matrix pose different levels of legitimacy and negotiating capabilities vis-à-vis regional cultural sectors, whose relations with public administration follow different logics and aims. Yet these dissimilarities also provide us with elements to gauge how corporate interests and cultural governance are structured in each region and stem from very different economic and policy aims.

In this respect, both the cultural policy model and its forms of horizontal governance have been heavily influenced by the identity factor (whether national or not). This variable has been of no importance whatsoever in Madrid. In contrast, in Catalonia the 'national' issue has been a source of conflict when drawing up artistic and cultural projects and as an element of cohesion in corporatist approaches to governance and in grassroot cultural initiatives. The 'identity issue' has not led to tension in the cultural policies of Andalusia and Madrid with regard to the role played by the Capital. Yet in Catalonia, 'cultural identity' has been keenly debated in connection with Barcelona's position. Here, one should recognise that this factor dynamises cultural activity in the relationships between government and social actors, fostering interpretation of cultural policies and encouraging initiatives abroad as elements that can contribute to 'nation-building' (Zamorano, 2015).

Table 2. Cultural data by Autonomous Community [self-governing regions] (2015)

\begin{tabular}{|c|c|c|c|c|}
\hline & & ANDALUSIA & MADRID & CATALONIA \\
\hline \multirow{2}{*}{ THEATRE COMPANIES } & & 418 & 824 & 770 \\
\hline & $\%$ State spending & $11.5 \%$ & $22.6 \%$ & $21.2 \%$ \\
\hline \multirow{2}{*}{ THEATRICAL PERFORMANCES } & & 3,307 & 15,274 & 10,255 \\
\hline & $\%$ State spending & $7.1 \%$ & $32.7 \%$ & $21.9 \%$ \\
\hline MUSEUMS & & 180 & 118 & 130 \\
\hline (COLLECTION IN CENSUS) $\mathbf{1 9}$ & $\%$ State spending & $11.8 \%$ & $8.5 \%$ & $7.8 \%$ \\
\hline \multirow{2}{*}{$\begin{array}{l}\text { BOOKS REGISTERED } \\
\text { WITH THE ISBN AGENCY }\end{array}$} & & 10,460 & 28,830 & 20,503 \\
\hline & $\%$ State spending & $13.2 \%$ & $36.3 \%$ & $25.8 \%$ \\
\hline \multirow{2}{*}{$\begin{array}{c}\text { ACTIVE FILM PRODUCTION } \\
\text { COMPANIES }\end{array}$} & & 31 & 116 & 97 \\
\hline & & 9.0 & $33.8 \%$ & $28.3 \%$ \\
\hline
\end{tabular}

SOURCE: Annual Culture Statistics 2016, ([Ministry for Education, Culture, Sport / INE]) 
In conclusion, as shown in Table 3, there are various differential factors determining the three governance models examined in this paper. There are also different strategies for dealing with different social demands. Yet all the regional governments exhibit a certain isomorphism in terms of the predominant top-down governance of the 1990s/2000s. They all adopt different forms of corporatism in their implementation. This issue can partly be explained by the persistence of the same parties in the administration of each region for over two decades (PP in the Madrid region from 1995 to the present; PSOE in Andalusia from 1978 to the present, and CiU in Catalonia between 1980 and 2003). While corporatist (and occasionally clientelist) cultural management in Andalusia was basically of a financial nature, in Madrid—with less public intervention—stable corporate networks did not arise. In the Catalan case, they did and were mainly of a nationalist nature. Thus, the 'identity' element can explain the greater intensity and strategic vision of public intervention in culture in both Andalusia and in Catalonia (Rodríguez and Rius, 2012b, p. 13). The greater socio-institutional convergence (mainly in the Catalan case) should not be seen as a single variable determining closed or corporatist governance. In contrast, various ways of intrumentalising cultural policy and finances, linked to path dependence of the historic corporatist-clientalist model found in Mediterranean countries (Esping-Andersen, 2000, p. 90), may explain both this phenomenon and top-down forms of governance.

Table 3. Comparisons between forms of governance in Catalonia, Madrid, and Andalusia

\begin{tabular}{|c|c|c|c|}
\hline VARIABLES & CATALONIA & MADRID & ANDALUSIA \\
\hline $\begin{array}{l}\text { Model } \\
\text { of horizontal } \\
\text { governance }\end{array}$ & $\begin{array}{l}\cdot+\text { top down-bottom up } \\
\text { - Corporatism }\end{array}$ & $\begin{array}{l}\text { - top down (weak) } \\
\text { - Client corporatism }\end{array}$ & $\begin{array}{l}\cdot \text { + top down-bottom up } \\
\text { - Client corporatism }\end{array}$ \\
\hline Main discourse & $\begin{array}{l}\text { (1) National } \\
\text { (2) Creativity }\end{array}$ & $\begin{array}{l}\text { (1) Cultural diversity, creativity } \\
\text { (2) Limited 'national' content }\end{array}$ & $\begin{array}{l}\text { (1) Modernising } \\
\text { (2) Mixed Andalus and Spanish }\end{array}$ \\
\hline $\begin{array}{c}\text { Vertical } \\
\text { governance }\end{array}$ & $\begin{array}{l}\text { - Scant articulation } \\
\text { with central government } \\
\text { - Regional disarticulation } \\
\text { (DIBA and Barcelona } \\
\text { council local governments) }\end{array}$ & $\begin{array}{l}\text { - Articulation/isomorphism } \\
\text { with the Ministry of Culture } \\
\text { - Articulation/delegation } \\
\text { in relation to administration } \\
\text { of the Capital }\end{array}$ & $\begin{array}{l}\text { - Articulation and institutional } \\
\text { transfers with central tier } \\
\text { - Co-ordination with provincial } \\
\text { and local governments }\end{array}$ \\
\hline $\begin{array}{l}\text { Centres } \\
\text { and peripheries } \\
\text { in the regional } \\
\text { cultural system }\end{array}$ & $\begin{array}{l}\text { - Barcelona 'Capital' is the } \\
\text { centralising nucleus } \\
\text { - Tension: Barcelona } \\
\text { Capital-interior }\end{array}$ & $\begin{array}{l}\text { - Madrid-Capital is the } \\
\text { articulating nucleus } \\
\text { - Tension between the Capital } \\
\text { and metropolitan area }\end{array}$ & $\begin{array}{l}\text { - Seville, Malaga, Cordoba, } \\
\text { Granada } \\
\text { - Different focii: Decentralised }\end{array}$ \\
\hline
\end{tabular}

SOURCE: author

\section{REFERENCES}

Aja, E. (2007). El Estado autonómico: federalismo y hechos diferenciales. Madrid: Alianza Editorial.

Barbieri, N. (2015). A narrative-interactionist approach to policy change analysis. Lessons from a case study of the cultural policy domain in Catalonia. Critical Policy Studies, 9(4), 434-453.

Barbieri, N. (2012a). Why does cultural policy change? Policy discourse and policy subsystem: a case study of the evolution of cultural policy in Catalonia. International Journal of Cultural Policy, 18(1), 13-30. 
Barbieri, N. (2012b). ¿Por qué cambian las políticas públicas? Una aproximación narrativa a la continuidad, el cambio y la despolitización de las políticas culturales. El caso de las políticas culturales de la Generalitat de Catalunya (1980-2008) PhD Thesis. Universitat Autònoma de Barcelona, Barcelona.

Blomgren, R., and Johannisson, J. (2014). Regional Cultural Policy in Sweden: Empirical Results, Theoretical Understandings and Consequences for Cultural Policy Research. Communication presented at the 8th International Conference on Cultural Policy Research, 12-13 ${ }^{\text {th }}$ September 2014, Hildesheim.

Bonet, L., and Negrier, E. (2010). Cultural policy in Spain: processes and dialectics. Cultural Trends, 19(1), 41-52.

Bouzada, X. (2007). La gouvernance de la culture en Espagne. In L. Bonet and E. Négrier (ed.), La politique culturelle en Espagne (p. 15-34). Paris: Karthala.

Chávez, M. A. (2012). Los consejos de las artes y el principio de "arm's length" en las políticas culturales subnacionales: Un estudio comparativo entre Cataluña (España), Escocia (Reino Unido) y Jalisco (México). PhD Thesis. Universitat de Barcelona, Barcelona.

Consejería de Educación y Cultura (1995). La Política cultural en la Comunidad de Madrid: objetivos y vías de acción: informe final del libro blanco de la cultura de la Comunidad de Madrid. Madrid: Comunidad de Madrid, Consejería de Educación y Cultura.

Crameri, K. (2008). Catalonia: National Identity and Cultural Policy 1980-2003. Cardiff: University of Wales Press.

Departament de Cultura (1983). Memoria de actividades. Barcelona: Generalitat de Catalunya.

Dubois, V. (1999). La politique culturelle. Genèse d'une catégorie d'intervention publique. Paris: Belin.

Esping-Andersen, G. (2000). Fundamentos sociales de las economías postindustriales. Barcelona: Ariel.

Fernàndez, J. A. (2008). El malestar en la cultura catalana. La cultura de la normalització (1976-1999). Barcelona: Empúries.

Font, J. (1991). Papers de política cultural. Barcelona: Edicions 62.

García de Enterría, E. (1983). Madrid Comunidad Autónoma Metropolitana. Madrid: Instituto de Estudios Económicos.

Garretón, M.A. (2008). Las políticas culturales en los gobiernos democráticos en Chile. In A. A. Canelas and R. Bayardo (ed.), Politicas Culturais Na Ibero-América (p. 75-117). Salvador de Bahía: Editora da Universidade Federal da Bahia.

Gattinger, M., and Saint-Pierre, D. (2008). Can national cultural policy approaches be used for sub-national comparisons? An analysis of the Québec and Ontario experiences in Canada. International Journal of Cultural Policy, 14(3), 335-354.

Giner, S., Flaquer, L., Busquet, J., and Bultà, N. (1996). La cultura catalana: el sagrat i el profà. Barcelona: Edicions 62.

Gray, C. (2008). Instrumental policies: causes, consequences, museums and galleries. Cultural trends, 17(4), 209-222.

Hillman, H., and McCaughey, C. (1989). The Arm's Length Principle and the Arts: An International Perspective-Past, Present and Future. In M. C. Cummings and J. M. Schuster (ed.), Who's to Pay for the Arts?: The International Search for Models of Support (p. 1-30). New York: American Council for the Arts.

Johannisson, J. (2010). Making Geography Matter in Cultural Policy Research: The Case of Regional Cultural Policy in Sweden. In J. P. Singh (ed.). International Cultural Policies and Power (p.127-139). New York: Palgrave Macmillan.

Kangas, A. (2001). Cultural Policy in Finland. The Journal of Arts Management, Law, and Society, 31(1), 57-78.

Kangas, A., and Vestheim, G. (2010). Institutionalism, cultural institutions and cultural policy in the Nordic countries. Nordisk Kulturpolitisk Tidskrift, 13(2), 267-286.

Lebovics, H. (2000). La misión de Malraux. Salvar la cultura francesa de las fábricas de sueños. Buenos Aires: EUDEBA.

López, J. F. (1999). El Canadà i Espanya: una comparació des del federalisme contractual. Autonomies. Revista Catalana de dret públic, 25, 7-36.

Martínez, S., and Rius, J. (2012). La política cultural de la Diputación de Barcelona. La influencia del contexto político institucional y de la articulación entre administraciones en el desarrollo de un modelo singular de cooperación cultural. Revista de Investigaciones Políticas y Sociológicas, 11(1), 9-37.

Mascarell, F. (ed.). (1999). El llibre blanc de la cultura a Catalunya: un futur per a la cultura catalana. Barcelona: Edicions 62.

Menger, P. M. (2010). Cultural Policies in Europe. From a State to a City-Centered Perspective on Cultural Generativity. GRIPS. National Graduate Institute for Policy Studies, 10(25).

Miller, T., and Yúdice, G. (2004). Política cultural. Barcelona: Gedisa.

Mulcahy, K. (1998). Cultural Patronage in Comparative Perspective: Public Support for the Arts in France, Germany, Norway, and Canada. Journal of Arts Management, Law and Society, 27(4), 247-263. 
Parker, R., and Parenta, O. (2009). Multi-level order, friction and contradiction: the evolution of Australian film industry policy. International Journal of Cultural Policy, 15(1), 91-105.

Pérez, M., and Vives, P. (2012). La política cultural en Andalucía. Revista de Investigaciones Políticas y Sociológicas, 11(3), 65-88.

Peters, G. (1995). Modelos alternativos del proceso de la política pública. De abajo hacia arriba o de arriba hacia abajo. Gestión y Política Pública, 4(2), 257-276.

Peters, G., and Savoie, D. J. (eds.). (1995). Governance in a changing environment. Montreal: Canadian Centre for Management Development, Centre canadien de gestion, McGill-Queen's University Press.

Pongy, M., and Saez, G. (1994). Politiques culturelles et régions en Europe. Paris: L'Harmattan.

Real Instituto Elcano de Estudios Internacionales y Estratégicos (2004). La política cultural en España. Madrid: Real Instituto Elcano de Estudios Internacionales y Estratégicos.

Rius, J. (2005). Un nou paradigma de la política cultural. Estudi sociològic del cas de Barcelona. PhD Thesis. Universitat Autònoma de Barcelona, Barcelona.

Rius, J. (2010). Els contractes programa dels equipaments culturals. Governança, eficiència i retorn social del sistema públic d'equipaments culturals de Catalunya. Barcelona: Generalitat de Catalunya.

Rius, J., Rodríguez, A., and Martínez, S. (2012). El sistema de la política cultural en Cataluña: un proceso inacabado de articulación y racionalización. Revista de Investigaciones Políticas y Sociológicas, 11(3), 173-204.

Rius, J., and Rubio, J. A. (eds.). (2016). Treinta años de políticas culturales en España. Participación cultural, gobernanza territorial e industrias culturales. Valencia: Servei de Publicacions de la Universitat de València.

Rius, J., and Zamorano, M. M. (2014). ¿Es España un estado casi-federal en política cultural? Articulación y conflicto entre la política cultural del estado central y la del gobierno de Cataluña. Revista d'estudis Autonòmics i Federals, 19, $274-309$.

Rodríguez, A., and Rius, J. (ed.). (2012a). El sistema de la política cultural: el caso de las políticas culturales autonómicas (monográfico extraordinario). Revista de Investigaciones Políticas y Sociológicas, 11(3).

Rodríguez, A., and Rius, J. (2012b). Presentación del monográfico sobre la política cultural en España: los sistemas autonómicos. Revista de Investigaciones Políticas y Sociológicas, 11(3), 9-14.

Rodríguez, A., and Rubio, J. A. (2007). Las subvenciones públicas a las artes escénicas en España. Informe de Investigación para la Red Nacional de Teatros y Auditorios de España. Barcelona: Universidad de Barcelona. Accessed on the 20th of April 2017 at http://www.redescena.net/descargas/proyectos/informe_final_subven_artes_escenicas.pdf

Rubio, J. A. (2005). La política cultural del Estado en los gobiernos populares (1996-2004): entre el ¿liberalismo? y el continuismo socialista. Revista Sistema, 187, 111-124.

Rubio, J. A. (2008a). Génesis configuración y evolución de la política cultural del estado a través del Ministerio de Cultura: 1977-2007. Revista de Investigaciones Políticas y Sociológicas, 7(1), 55-70.

Rubio, J. A. (2008b). La política cultural de los Gobiernos Autonómicos de la Comunidad de Madrid: su singularidad en el contexto autonómico español. Revista de Investigaciones Políticas y Sociológicas, 11(3), 205-234.

Rubio, J. A., and Bonnin, P. (2009). La institucionalización de la política cultural de la Comunidad de Madrid: El caso de las compañías de Danza residentes en los municipios. Madrid: Universidad Antonio de Nebrija. Accessed on the 20th of April 2017 at http://fes-sociologia.com/files/congress/11/papers/1003.doc

Rubio, J. A., and Rius, J. (2012). La modernización de la gestión pública de la cultura. Análisis comparado del caso de los equipamientos culturales de las comunidades autónomas de Cataluña y Madrid. Gestión y Análisis de Políticas Públicas, 8, 11-34.

Santos, J. M. de los (1991). Sociología de la transición andaluza. In I. Moreno (coord.), La identidad cultural de Andalucía (p. 211-225). Málaga: Librería Ágora.

Subirós, J. (1998). El vol de la fletxa. Barcelona '92: Crònica de la reinvenció de la ciutat. Barcelona/Madrid: Centre de Cultura Contemporània de Barcelona/Electa.

Taylor, C. (1997). La política del reconocimiento. In Argumentos filosóficos (p. 293-334). Barcelona: Paidós.

Urfalino, P. (1996). L'invention de la politique culturelle. Paris: La Documentation Française.

Vidal, J. (1997). Hacia Una fundamentación teórica de la política cultural. Revista Española de Investigaciones Sociológicas, 16, 123-134.

Villarroya, A. (2012a). Country Profile: Spain. In ERICArts / Council of Europe (ed.), Compendium of Cultural Policies and Trends (p. 1-88). Bonn: ERICArts / Council of Europe.

Villarroya, A. (2012b). Cultural policies and national identity in Catalonia. International Journal of Cultural Policy, 18(1), $31-45$. 
Wiarda, H. J. (1996). Corporatism and comparative politics. New York: M. E. Sharpe.

Zallo, R. (2011). Análisis comparativo y tendencias de las políticas culturales de España, Cataluña y el País Vasco. Madrid: Fundación Alternativas.

Zamorano, M. M. (2015). La disputa por la representación exterior en la política cultural contemporánea: el caso de la paradiplomacia cultural de Cataluña. PhD Thesis. Universitat de Barcelona, Barcelona.

Zamorano, M. M., and Rius, J. (2014). ¿Es España un Estado casi-federal en política cultural? Articulación y conflicto entre la política cultural del Estado central y la del gobierno de Cataluña. Revista d'Estudis Autonòmics i Federals, 19, $274-309$.

Zamorano, M. M., and Rius, J. (2016). ¿La diplomacia cultural, una política de Estado? Articulación y descoordinación intergubernamental en la acción cultural exterior del Estado español. Revista d'Estudis Autonòmics i Federals, 24, 115-154.

Zimmer, A., and Toepler, S. (1996). Cultural Policies and the Welfare State: The Cases of Sweden, Germany, and the United States. The Journal of Arts Management, Law and Society, 26, 167-193.

Zimmer, A., and Toepler, S. (1999). The Subsidized Muse: Government and the Arts in Western Europe and the United States. Journal of Cultural Economics, 23, 33-49.

Zolberg, V. L. (2007). Los retos actuales de la política cultural: una nueva idea de comunidad. In A. Rodríguez (ed.), La sociedad de la cultura (p. 89-107). Barcelona: Ariel.

\section{BIOGRAPHICAL NOTE}

Mariano Martín Zamorano holds a PhD in Cultural and Heritage Management from Barcelona University. He is also an Associate Professor and member of CECUPS on institutional matters. Zamorano has a long track record in carrying out interdisciplinary academic projects (AECID, Ministry of Education, the European Commission, and so on), and has published various papers in leading scholarly journals, a book chapter, and a co-written book currently in press. 


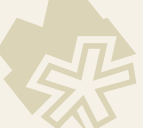

